\title{
THE PROBLEMS OF DEVELOPMENT OF NATIONAL STATE
}

\author{
Antanas Makštutis \\ The General Jonas Žemaitis Military Academy of Lithuania, \\ BOX - 812, LT-10014 Vilnius, Lithuania \\ E-mail:Malgas@mail.lt \\ Received 10 April 2006; accepted 3 January 2007
}

\begin{abstract}
The paper analyzes the global economic factors of the development of the national state in the European Union (EU). The place of the national state is shown under globalization in the common EU space where under the conditions of a free market complicated tasks are being formed: development of progress, promotion of democracy in the territory of the state, and activation of the public activity. Problems of the national state and public development as well as ways of their solution are described. Analysis is given of the opportunities for modernization of the organization in the national market and the common EU space, factors related to optimization of human labour are determined and presented, and methods are foreseen for solving the future political, economic and social problems in the EU under the conditions of globalization.
\end{abstract}

Keywords: national state, society, development, market, progress, democracy, labour, product, cost, price, capital, model, factors, security, problems.

\section{Introduction}

Scientific and practical problem of the work is to explore the factors of globalization, which impact the EU political, economic and social system under the conditions of the global market, to identify the place of the national state in the EU in the 21st century and developmental trends that are specified by the development of progress and democracy on the national market [1]. Progress and democracy factors form the prospects for the development of the individual, family and organization in the EU space, which are regulated by the national state and the EU. On the other hand, the EU is a constituent part of the global economy and takes a strategically important place in European-Asian-African region in the field of national, continental and global security. Problem analysis created conditions for formulation of research objective and tasks [2].

The objective of research is to determine the national development trends in the EU and the world in the 21 st century.
Research tasks are to analyze the trends of the national state development system, progress and democracy processes and factors, to present a national state model and steps for its implementation in the 21st century under the conditions of globalization, and to formulate the conclusions for modernization of an organization.

Research results are to forecast the trends for modernization of an organization under the global economy and market conditions in the national state, the EU, and the world.

In the present study, the use is made of the material of research carried out in Lithuania within 2000-2006, the most advanced scientific and other national, EU and world information data sources, which created conditions for formulation of the key theoretical and practical approaches presented in this work [3]. Research results allow one to forecast the activity of the 21 st century organization in the national state under the conditions of the EU global economy, to formulate theoretical and practical provisions in respect of labour. 
The state is the most significant system of the balanced development of the political organizations of the society, through which the progress and democracy development factors are controlled for speeding up the balanced development of the society on the national market, wherein an impact is made on the human labour, family life, labour results of a separate collective in the organization. The general economic, political and social structure of the society, individual, family and collective (in the organization) is secured, and progress of developmental processes, characteristic of the 21 st century in the global world, is constantly ensured [4].

The labour activity, which is expressed by the work performed per calendar year (or per activity cycle), explains how the most important features of the state, intended for the improvement of the management and self-management system in the national state and EU common market under the conditions of global economy, are revealed in the society, national economy, and the market. The management theory provided in the work is characteristic of all the states in the world to-date and in the future [5].

According to this theory, the most important features of the national state in the 21 st century society are distinguished and characterized by [6]:

- the special system of institutions, which is intended for performance of government functions;

- the right to perform government functions strictly according to the normative system of acts ("NAS") of the state;

- the state territory, which is limited by the borders and where the government functions are implemented for the development of progress and democracy of the organizations according to their normative system of acts ("nas").

The features of the state in the society provide equal conditions for optimization of human labour, family life and activity of the organization in using progress, developing democracy in the society, since the government executive functions are implemented according to "NAS" (constitution, laws and other normative acts). Therefore the system of the organizations of the national state, which exercises management, must undertake personal responsibility for the speed of progress and development in the national market, since democracy in the society is expressed through self-management (human labour in the family life and organization by actual results) [7].

Democracy is expressed by the self-management, which is implemented in the life of the individual and the family, management of the activity of the collective inside and outside the organization according to "nas" of the organization. The mutual factors of "NAS" and "nas" regulate the degree of public democracy in the national state and the common EU market in the world [2].

\section{Progress and democracy}

The progress and democracy factors may be subdivided into macro- and microfactors. Macrofactors are characterized by political, economic and social factors [8]. The efficiency of the management and selfmanagement system of these factors is expressed by macroeconomic indicators within the year in the national economy, market and society as [2]:

- state national budget and its balance (income less than expenses);

- national market balance (export less than import);

- unemployment - the ratio of the number of unemployed people with the number of people able to work actually;

- the average standard of living, expressed by the ratio of the real income and normative state expenses per capita;

- minimum wage - the normative wage established by the state;

- minimum standard of living - the normative established by the state per capita, on the average;

- investment speed - the average volume of investment per capita in the country;

- demand - the real purchasing power, calculated, on the average, per capita in the country;

- supply - the volume of the products manufactured in the national economy and placed on the market (calculated, on the average, per capita in the country);

- strategic programmes of the development of the national economy, separate branches of the economy, regions and local economy (the actual number);

- other national market factors (agreements, protocols of intention, and projects).

These macroeconomic indicators are specific for all the states in the world, therefore in the national state the labour results, achieved in developing progress and democracy, define, in the essence, the management and self-management efficiency, which is evaluated by the already mentioned criteria and indicators [9]. Work is carried out by the collective in the concrete organization. Therefore the efficiency of the management of progress and democracy and factors of the self-management of the organization are expressed by economic indicators per year as: [2]: 
- organization activity balance (income less than expenses);

- product cost price;

- product price;

- product profit;

- average wages of the worker;

- capital of the organization (real estate, investment and money);

- annual labour programme;

- number of jobs;

- level of modernization of jobs (by application of progress);

- labour efficiency;

- competence of employees (capacity to apply progress);

- application of progress (new product, new materials, new technologies, new equipment, new jobs and labour efficiency);

- purchase volumes;

- sales volumes;

- product stock;

- other factors for optimization of the organization activity (strategic and perspective programmes, agreements, protocols, and projects).

These microeconomic indicators characteristic of all business organizations, they are also important for the system of state organizations since they are intended for evaluation and optimization of its activity efficiency [10].

The macroeconomic indicators of the national market depend on the microeconomic indicators, and all of them are under direct effect of progress and democracy processes under global economic conditions. Therefore in the 21st century the management factors in the national state and self-management factors in the organization make an impact on the balanced development of the state and society under the EU global market conditions [11].

In the national state with the average standard of living, it is important that the accumulation function of the separate individual per year would be more than unit, since unit expresses the average real consumption needs per family member in the national market. It is the real accumulation function that provides the opportunity to develop progress [6].

Such criterion for the evaluation of the development of progress and democracy in the state is essential in the 21 st century.

Progress factors and objects. It was established by research that progress factors and objects in the balanced development of the society and the state are as follows [3]:
- factors - political, economic, social;

- objects - national state budget, national market balance, labour, development strategy of national economy, its separate branches, regions, cities, districts, programmes and projects (strategic, perspective and operative plans for the implementation of programmes and projects).

State national budget is aimed at ensuring the development of political, economic and social factors for the balanced development of the society and the national state and development of progress, therefore its optimum balance shall be equal to zero [6].

National market balance is expressed by the difference in the volumes of export and import [3]. Therefore progress development is optimum when national market balance is positive, and the result is worst when national market balance is negative. In this case (in the state) the value of labour reduces, the number of jobs does not increase, demand for the market (or the purchasing power of people) decreases, and supply of the market is ensured at the account of import volumes (the labour value of people of other states is imported and sold) [2].

Thus, progress development is not promoted, modern organizations (small, medium, large: of the manufacturing industry, creation and realization of new products) and new modern jobs are not established, therefore it is especially difficult to organize and implement investment projects, which would ensure the balanced development of the society and the state.

Democracy factors and objects. It was identified by research that democracy factors and objects in the life of the individual, family development, and in extending the activity in the organization under global economic conditions are as follows [3]:

- factors - external factors of the political, economic and social environment of the national state (characterizing "NAS" of the state) and internal factors of the organization (characterizing "nas" of the organization), which impact the life of the individual and the family, self-management of the collective in the organization through the labour results and also express the prospects of the management efficiency of the system of state organizations;

- objects - national wealth (national resources: natural resources, real estate, investment, money), product, human labour, profit, cost price, wages, income, expenses, creation and application of progress, imported resources, miscellaneous (state action strategy, programme, investment environment, national and global market). 
The whole capital of the individual, of the family and of the collective in the organization is intended for the development of progress and organization of the efficient work of the individual, whereas the labour results show the speed of the application of progress in the national and EU market in the world. This means that the development of all factors and objects of democracy depends in the essence on the development of labour and capital. This development ensures the improvement of the systems of the management of the state and self-management of the organization in the national market, therefore the national capital increases and capital concentration occurs. Capital concentration manifests itself when the amount of money increases [12]. Then it is possible to increase the volumes of investment and real estate, which under the global economic conditions increase the amount of money again. These processes are developing by realization of labour results in the national, EU and world markets under the global economic conditions [13]. The results achieved by human labour in the organizations create the real conditions for the human and family life, therefore special attention by the state management system should be accorded to business organizations through "NAS", then the democracy factors in the organizations will ensure the improvement of the "nas" in the organization [4].

The efficiency of the organization activity increases when the key factors are constantly evaluated optimally and are established in the employees' organization: objectives, normatives, planned and real results. These activity conditions are characteristic of all organizations in the state and the world community at starting and completing the calendar year, since it is this environment that creates conditions for the development of democracy and progress in the $21 \mathrm{st}$ century [14]. After making analysis of the global economic impact and the national market factors, the generalizations, forming conditions for the creation of the state model [6], may be presented for improvement of the management and self-management system.

The national state model conditions foresee [3]:

- To restructure the state management system and attribute to this system the society and state development strategy, programmes, progress, and democracy.

- To restructure the self-management system of the organization and attribute to this system human labour, optimization of the activity of the organization.

- 21 st century action prospects only for modern organizations, therefore their activity is specified by objectives, programmes, tasks, evaluation criteria, resources, normatives, planned and real labour results.

\section{National state}

Firstly, the state is independent in the world community. In the 21 st century, the vision and mission of the national state got changed in the essence and, accordingly, the state management system.

Secondly, national market relations underwent changes under global economic conditions, affecting the state and social relations, which are characterized by the political, economic and social factors of the national state in the 21 st century.

Thirdly, rates of the development of the national state and society are slowing down, therefore the totality of negative and positive factors increases and is characterized by inflation, competition, conjuncture, unemployment, bankruptcy, demand, supply, import, export, resources, migration, other national and global market factors [15].

The world economic and global market factors (free movement of capital, goods and services, people) make a direct impact on the national state management efficiency, which may be increased only by implementing the balanced development model of the society and the state under the conditions of globalization, which is given below [3].

The national state model.

1. To transform the existing management system into the management-self-management system of national economy (model: "nasNAS and NAS-nas"), which would develop democracy under the 21 st century conditions. Place of implementation of Article 1 of the model - the state and society. Responsible for implementation - the national state parliament.

2. To prepare and implement a scientific-technical progress model in the state (for optimization of the human, family, collective /in the organization/ activity, model: "nas-NAS and NAS-nas"), which would ensure the manufacture of the national product and market development under global economic conditions. Place of implementation of Article 2 of the model - the state and society. Responsible for implementation - the national state government.

3. Improvement of political, economic, social factors (a social self-management model: 
"nas - NAS and NAS - nas") in the national state under the globalization conditions. Place of implementation of Article 3 of the model organizations. Responsible for implementation - management and specialists of organizations.

4. To create the optimum activity environment for organizations (a social self-management model: "nas - NAS and NAS - nas") under global market conditions. Place of implementation of Article 4 of the model - organizations. Responsible for implementation - management and specialists of organizations.

5. To plan optimum activity factors in the organizations and to manufacture a new product (a social self-management model: "nas NAS and NAS - nas") under global market conditions. Place of implementation of Article 5 of the model - organizations. Responsible for implementation - management and specialists of organizations.

6. To plan the optimum activity factors in the organizations and to increase the national product volumes (a social self-management model: "nas - NAS and NAS - nas") under global market conditions. Place of implementation of Article 6 of the model - organizations. Responsible for implementation - management and specialists of organizations.

The balanced development model is intended for optimization of labour of the collective in the organization, the human and family life conditions in the national state under the global market conditions in the world [2].

Implementation of this model in practice creates all conditions for the balanced development of the society and the state under the EU global economic conditions in the 21st century in the world [3].

Statistical data confirm that in separate states political and economic factors are constantly moving away from social factors, as a result of which security cooperation of people in the world will be very vulnerable in the 21 st century, and special attention should be devoted to the strengthening of national, regional, continental and global security [15].

\section{Conclusions}

The conclusions and problems presented above are characteristic of all the states in the Baltic Sea region, the regional cooperation between West-East and East-West in the common EU and the world.
Research factors of regional cooperation in the conditions of Lithuania's integration into the EU revealed wide opportunities for a comprehensive analysis of external and internal threats to the national state as well as for evaluation of the impact of the changes of political, economic and social factors on the geopolitical environment of Lithuania in time and space. Conclusions are based on the methodological principles in investigating external and internal threats to regional cooperation in the EU, methodics and methods of their implementation.

1. It is the harmonization of the development of political, economic and social factors that will assure the balanced development of the state and society under conditions of Lithuania's integration into the EU.

2. Integration into the $\mathbf{E} \mathbf{U}$ creates positive conditions for strengthening national cooperation in time and space (in Lithuania, the EU and in the world).

3. Today, however, the existing political, economic, and social factors of the internal environment in Lithuania are unfavourable to the investors from the $\mathbf{E U}$, since the tax system and price policy in the national market constantly increase the cost price of the national product for business organizations, as a result of which the compatibility of business organizations goes on reducing in the national, EU and world markets.

4. The institutions of Lithuania must review in the essence the national tax policy, create favourable conditions for investment of national and foreign capital into Lithuania's economy.

5. The national business organizations due to the tendencies towards increasing the product cost price do not possess the real economic conditions for wage increase of the employees, and because of these reasons the purchasing power of the population in the national market goes on decreasing, the annual inflation rate amounts to over $3 \%$, and the social environment is becoming worse.

6 . The factors of the social environment accelerate the emigration of young people, its scale going up, and within the nearest 15 years over 500,000 young people will emigrate from Lithuania, the demographic environment will become worse for a long period, as a result of which the number of the population in Lithuania in 2016 may go down from $3,000,000$ to $2,750,000$ of $3,500,000$ today.

7. The national business organizations should 
search other economic methods and ways for their integration into the activities of international corporations under the conditions of global economy.

8. The institutions of Lithuania must solve the problems of reduction of importflows from the East (to $50 \%$ ) and limit the import of low-quality goods (to $100 \%$ ) into the national market.

The conclusions and problems presented above are characteristic of all the states in the EU and the world.

\section{References}

1. Lithuanian Membership in the EU and the Effects of Quality Management Upon National Economy. The Editorial Committee. Kaunas: Technologija, 2004.

2. MAKŠTUTIS, A. Total Quality Management of Globalization Conditions. Vilnius: Academy press, 2005.

3. MAKŠTUTIS, A. Strategic Planning of Globalization Conditions. Vilnius: Academy press, 2006.

4. Tendency of National Security in the Baltic Sea Region. Edited by Antanas Makštutis. Vilnius: Academy press, 2006.

5. The Security of Regional Cooperation. Edited by Antanas Makštutis. Vilnius: Academy press, 2005.

6. MAKŠTUTIS, A. The Principles of Strategic Management. Klaipėda: University press, 2001.
7. Future Lithuania in the World Context: Experts' View. Edited by V. Jasiulevičius and A. Makštutis. Vilnius: Mokslo aidai, 2003.

8. FITZROY, P.; HULBERT, J. Strategic Management. Creating Value in a Turbulent World. West Sussex: Jon Wiley \& Sons, Inc., 2005.

9. The Area of Freedom, Security and Justice in the Enlarged Europe. Edited by Karen Henderson. New York: Palgrave Macmillan, 2005.

10. MEAD, R. International Management. Cross-Cultural Dimensions. Malden, Oxford: Blackwell Publishing, 2005.

11. AAKER, D. A. Strategic Market Management. Hoboken: Jon Wiley \& Sons, Inc., 2005.

12. THOMPSON, Jr. A. A., STRICKLAND III, A. J. Strategic Management: Concepts and Cases. New York: Thomson, 2004.

13. HITT, M.; IRELAND, R. D.; HOSKISSON, R. E. Strategic Management. Competitiveness and Globalization. Ohio: Thomson, 2005.

14.Lineages of European Citizenship. Rights, Belonging and Participation in Eleven Nation-States. Edited by Richard Bellamy, Dario Castiglione and Emilio Santoro. London, New York: Palgrave Macmillan, 2004.

15.LOUGHLIN, J. Subnational Democracy in the European Union. Challenges and Opportunities. Oxford: University press, 2004. 